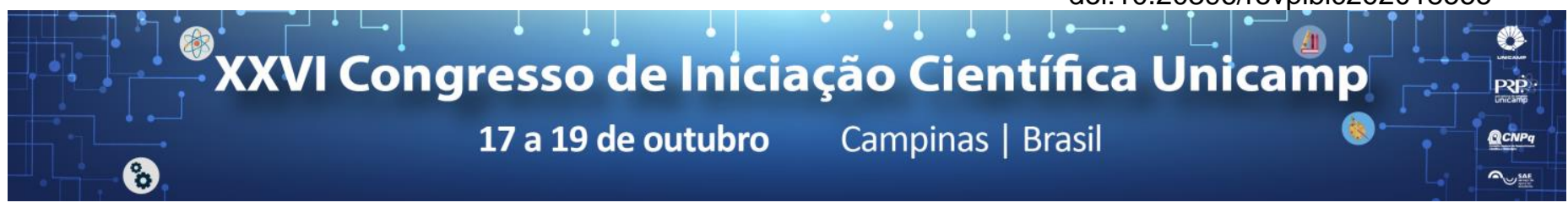

\title{
Levantamento e montagem de banco de dados sobre protestos e greves no Brasil (1999- 2016)
}

\section{Gleisson Henrique Belotti, Andreia Galvao}

\section{Resumo}

Este trabalho se insere num projeto de pesquisa coletivo que tem como objetivo realizar levantamento e montagem de um banco de dados sobre protestos e greves no Brasil realizados entre 1999 e 2016, período que corresponde ao segundo mandato de Fernando Henrique Cardoso e aos mandatos de Lula e Dilma. A intenção é mapear, nacionalmente, os registros de protestos de rua, a partir de um esforço sistemático de leitura do jornal Folha de $\mathrm{S}$. Paulo.

\section{Palavras-chave:}

Banco de dados; protestos; greves

\section{Introdução}

O banco de dados elaborado no decorrer da pesquisa contém, dentre outros, as seguintes variáveis:

1. Data de início do evento

2. Base social mobilizada

3. Ocupação (no caso de trabalhadores)

4. Alvo do protesto

5. Objetivos

6. Local do protesto

7. Número de participantes

8. Organização que convoca o protesto

9. Tipo de protesto

10. Confronto e violência (com a polícia e outros)

\section{Data de término}

O objetivo específico, ao dar continuidade à analise dos dados do banco, foi verificar se houve um certo "protagonismo" em termos de base social que foi às ruas no período máximo de eclosão de protestos da recente democracia brasileira desde 0 advento dos "caraspintadas", que exigiam a renúncia do então presidente Fernando Collor, em 1992. A presente pesquisa parte da hipótese teórica de que os protestos de Junho e Julho de 2013 estão associados a um mesmo ciclo histórico de mudanças, relacionadas às políticas implementadas pelos governos do PT que pode ser classificado como neodesenvolvimentista (Boito, 2018)1.

\section{Resultados e Discussão}

Através de uma codificação das bases sociais ligadas a território e ocupação - questões ligadas à produção e reprodução das condições de existência material-, buscouse testar as hipóteses presentes na bibliografia. A grande maioria dos 178 protestos noticiados no jornal "Folha de São Paulo" no referido período apontam para uma certa indeterminação quanto aos agentes em revolta, denotados pela categoria "Não Mencionado", que correspondem a $46 \%$ do total de entradas. A categoria "Trabalhadores", com aproximadamente $30 \%$ dos casos noticiados, vem logo em seguida, demonstrando o poder de mobilização e a força de suas diferentes frações sócio-econômicas afins: funcionários públicos e funcionários do setor de serviços, com ativa participação de seus sindicatos, contrariando hipóteses que enxergam um possível - senão decaimento da capacidade de representatividade dessas instituições. Através de um trabalho de minuciosa análise de cada registro dos "Não Mencionados", foi possível observar que, apesar de não descrita nas reportagens, a ação popular foi de caráter plurisocietal e econômico, com um espectro ideológico que vai desde liberais conservadores do $\mathrm{MBL}$ ao MST, MTST e Black Blocks.

\section{Conclusões}

Apesar de muitas ações serem encabeçadas, ao menos teoricamente, pelo Movimento Passe Livre, cujo perfil socioeconômico de seus apoiadores é de classe média, porém bem variado ${ }^{2}$, observou-se uma democratização da oportunidade política ${ }^{3}$ do ato de protesto, nas mais diversas ocasiões, pelas mais variadas demandas, num processo que se provou horizontal, apesar da forte onda anti-partidária que 0 assolou. A classe trabalhadora provou-se atenta ao ambiente político para ser mais agressiva em busca de seus direitos, ampliando seu escopo de luta, enquanto que o "cidadão médio" pôde, à sua maneira, sentir que estava mudando o país.

\section{Agradecimentos}

Gostaria de demonstrar imensa gratidão à minha família, aos meus amigos da República Bjos e à minha orientadora, Profa. Andréia Galvão. Por me compreenderem e apoiarem incondicionalmente quando tive de atravessar um período particularmente nebuloso de minha trajetória, nenhum agradecimento será suficiente. Agradeço também ao CNPQ, pelo fomento a esta pesquisa.

Boito Junior A. Reforma e crise política no Brasil: os conflitos de classe nos governos do PT. Campinas, SP: Editora da Unicamp; 2018.

2 Vainer CB. Cidades rebeldes: passe livre e as manifestações que tomaram as ruas do Brasil. São Paulo, SP: Boitempo; 2013.

${ }^{3}$ TARROW, Sidney. O Poder em Movimento: Movimentos Sociais e confronto político, Petrópolis, Editora Vozes, 2009[1998]. 